\title{
Training and retirement patterns
}

Citation for published version (APA):

Montizaan, R. M., Cörvers, F., \& de Grip, A. (2013). Training and retirement patterns. Applied Economics, 45(15), 1991-1999. https://doi.org/10.1080/00036846.2011.646066

Document status and date:

Published: 01/01/2013

DOI:

10.1080/00036846.2011.646066

Document Version:

Publisher's PDF, also known as Version of record

Document license:

Taverne

Please check the document version of this publication:

- A submitted manuscript is the version of the article upon submission and before peer-review. There can be important differences between the submitted version and the official published version of record.

People interested in the research are advised to contact the author for the final version of the publication, or visit the DOI to the publisher's website.

- The final author version and the galley proof are versions of the publication after peer review.

- The final published version features the final layout of the paper including the volume, issue and page numbers.

Link to publication

\footnotetext{
General rights rights.

- You may freely distribute the URL identifying the publication in the public portal. please follow below link for the End User Agreement:

www.umlib.nl/taverne-license

Take down policy

If you believe that this document breaches copyright please contact us at:

repository@maastrichtuniversity.nl

providing details and we will investigate your claim.
}

Copyright and moral rights for the publications made accessible in the public portal are retained by the authors and/or other copyright owners and it is a condition of accessing publications that users recognise and abide by the legal requirements associated with these

- Users may download and print one copy of any publication from the public portal for the purpose of private study or research.

- You may not further distribute the material or use it for any profit-making activity or commercial gain

If the publication is distributed under the terms of Article $25 \mathrm{fa}$ of the Dutch Copyright Act, indicated by the "Taverne" license above, 
Applied Economics

\section{Training and retirement patterns}

\section{R. Montizaan , F. Cörvers \& A. de Grip}

To cite this article: R. Montizaan , F. Cörvers \& A. de Grip (2013) Training and retirement patterns, Applied Economics, 45:15, 1991-1999, DOI: 10.1080/00036846.2011.646066

To link to this article: https://doi.org/10.1080/00036846.2011.646066

$$
\text { 曲 Published online: } 05 \text { Apr } 2012 .
$$

Submit your article to this journal $\sqsubset$

$$
\text { Џ Article views: } 397
$$

Q View related articles $\square$

4 Citing articles: 2 View citing articles 


\title{
Training and retirement patterns
}

\author{
R. Montizaan ${ }^{\mathrm{a}, \mathrm{b}, *}$, F. Cörvers ${ }^{\mathrm{a}, \mathrm{c}}$ and A. de Grip ${ }^{\mathrm{a}, \mathrm{b}, \mathrm{c}}$ \\ ${ }^{a}$ Research Centre for Education and the Labor market (ROA), \\ Maastricht University, PO Box 616, Tongersestraat 53, Maastricht, \\ The Netherlands \\ ${ }^{\mathrm{b}} I Z A$, Bonn \\ ${ }^{\mathrm{c}}$ Netspar, Tilburg
}

Life-cycle theory predicts that employers enter into implicit contracts with newly hired employees to ensure rent-sharing and to decrease turnover after firm-specific training investments. Typically, these implicit contracts would include both upward sloping earning profiles and mandatory retirement. In this article, we empirically test the prediction that workers with firm-specific skills are restrained in their options to continue working. Therefore, they are more likely to retire at common mandatory retirement dates than those with general skills. Using the US National Longitudinal Survey of Older Men, we find that workers who participated in firm-specific training in their early careers do indeed retire earlier than those with general skills. The results show that compulsory retirement plans force these older workers to retire when they reach the common mandatory retirement age of 65 . The results presented in this article are highly relevant for public policies in European and other industrialized countries that aim to increase labour force participation of the elderly. As our study demonstrates, the effectiveness of institutional arrangements to postpone retirement will also depend on training policies of employers and the type of skills workers acquired in the past.

Keywords: retirement; firm specific skills; general skills; implicit contracts

JEL Classification: J14; J31; J26

\section{Introduction}

Life-cycle theory predicts that firms enter into implicit contracts with newly hired employees in order to ensure rent sharing and to decrease turnover after firm-specific training investments. Those implicit contracts consist of upward sloping earning profiles that create a productivity-wage gap for older workers who acquired firm-specific skills in their early career. Therefore employers have incentives to include agreements on mandatory retirement into the implicit contracts to refrain these older workers from late retirement (see Lazear, 1979; Blinder, 1982). On the other hand, it is assumed that workers with general skills are paid equal to their value of marginal product. This makes employers indifferent to the retirement of workers who participated in general training courses, under the condition that no other transaction costs exist. This difference in the treatment of workers with firm-specific and general skills may have large consequences for retirement patterns. However, empirical studies on the relationship between employees' training background and retirement behaviour are scarce.

In this article, we contribute to the existing life-cycle literature by analysing the impact of workers' firm-specific and general training backgrounds on their retirement behaviour. By using information on training participation in their early career, we are able to increase insights in the causality between training background and retirement behaviour. The long period between the training participation we include in our analysis and the retirement date reduces the likelihood that workers were predominantly influenced by their retirement prospects when they made their decision to train. ${ }^{1}$

*Corresponding author. E-mail: r.montizaan@maastrichtuniversity.nl

${ }^{1}$ Montizaan et al. (2010) showed that postponing retirement of older workers increases their training participation. However, this only holds for those who are employed in large organizations. 
Moreover, we correct for workers' retirement preferences in order to further reduce the effects of potential self-selection into jobs that offer high pension coverage.

The article builds on the literature on the relation between deferred compensations and the preservation of human capital investments (Kennan, 1979; Blinder, 1982; Johnson, 1996; Fella, 2005). The starting point of this literature is the bilateral monopoly problem between the employee and employer after firm-specific training investments which may lead to undesirably high employee turnover. Employers and employees have to make an agreement on how the rents from firm-specific human capital investments will be shared after the investment. However, as Kennan (1979) and Blinder (1982) argued, any rent-sharing rule remains vulnerable to threats to terminate the contract by either side. These threats to terminate the contract arise because both workers and employers have an incentive to extract extra rent from the other party. The inability of employers to bind their workers results in a risk that they are not able to fully reap the rents of the training investment.

Kennan (1979) showed that implicit contracts with informal bonds can be used as an instrument by the employer to prevent bilateral monopoly problems and reduce turnover of workers with firm-specific skills. ${ }^{2}$ These implicit contracts include upward sloping earning profiles, mandatory retirement and a severance pay if workers are prematurely discharged. ${ }^{3}$ In the context of firm-specific training investments, deferred compensation can be seen as a bond to compensate employers for quitting while the obligation to pay severance pay in the case of a layoff can be seen as a bond to compensate the workers for the foregone future rents on their human capital investment. With deferred compensation, workers are paid less than the value of their marginal productivity when they are young and they are paid more when they become older. This gives workers an incentive to stay with their present employer, ensuring rent earnings for firms after firm-specific human capital investments. Because older workers with firm-specific skills earn more than their productivity at the end of their career, they will have an incentive to retire later, while employers have an incentive to terminate the labour contract at a certain age. Hence, in order to guarantee that the present discounted value of underpayments at the beginning of the career is equal to that of the overpayments at the end of the career, mandatory retirement is a necessary part of the implicit contract. On the other hand, employers have no incentives to enforce mandatory retirement of workers with general skills.

There are only a few empirical studies on the relation between human capital investments, earning profiles and retirement behaviour. Two related studies focused on the relationship between pension coverage and general and firmspecific training (Johnson, 1996; Dorsey and Macpherson, 1997). Both studies found a strong positive relationship between pension coverage and training. The latter found that firm-specific training has a larger effect on the likelihood of receiving pension coverage than general training. However, these studies did not analyse how retirement behaviour is affected by pension coverage.

Consistent with life cycle theory, we find that workers who received firm-specific training in their early careers retire earlier than workers with a general training background. Our estimation results show that mandatory retirement plans force these older workers out of the labour force when they reach the common mandatory retirement age of 65 . These findings are robust when using alternative training indicators and controlling for the effects of technological change or unobserved individual characteristics. This indicates that shared investments in firm-specific training are likely to be embedded in implicit contracts that aim to decrease turnover but also include restrictions on late retirement of the workers who acquired firm-specific skills.

This article is organized into five sections. In the next section, we will describe the data. Section III presents our empirical strategy. In Section IV, we will estimate the impact of workers' training background on retirement behaviour. Section V summarizes the findings and offers conclusions.

\section{Data}

Data sets that combine information on the type of training in which workers participated early in their career and on their retirement behaviour are extremely scarce. Panel data sets that focus on older workers, such as the US Health and Retirement Study (HRS) or the Survey of Health, Ageing and Retirement (SHARE) in Europe cover only older workers aged 50 and over and do not ask retrospective questions on human capital investments. An exception, however, is the US National Longitudinal Survey of Older Men (NLSOM) which we will use to estimate the effects of the training background of workers on their retirement behaviour. The NLSOM is a nationally representative survey of 5020 men in 1966 between the ages of 45 and 59 who were questioned periodically until 1983 and includes detailed information on employment history, training background, health limitations, demographics and personal characteristics. Individuals were interviewed 12 times at 1- and 2-year intervals.

The period we analyse is particularly interesting because it refers to the last years in which mandatory retirement was allowed in the United States. The large majority of workers who were subject to mandatory retirement were covered by defined benefit pension plans (Wachter, 2002). Since 1986, however, any form of compulsory retirement is forbidden in the US. This implies that the US together with Australia and Canada are the only countries that presently have an explicit ban on mandatory retirement. However, most European countries are only recently starting to change their mandatory retirement laws and still have extensive defined benefit pension plans, which implies that the legal environment in these

\footnotetext{
${ }^{2}$ Informal bonding can also be used to encourage employees to be trustworthy and not to shirk (see, Lazear, 1979; Lazear and Moore, 1984) and to reduce transaction costs that accompany recruitment and hiring.

${ }^{3}$ There exists a large literature that investigated the productivity-wage gap for older workers (e.g. Lazear, 1979; Medoff and Abraham, 1981; Blinder, 1982; Kotlikoff and Gokhale, 1992; Dostie, 2011). These studies measure wage slopes in order to test the prediction that the wage curve will be steeper than the productivity curve, and found that (i) earnings exceed productivity when old, and that (ii) job tenure and wage growth affect the likelihood of early retirement positively.
} 
countries is more comparable with the situation in the US before 1986.

During each interview, respondents in the NLSOM were asked about their major activity during the survey week. Based on this variable, retirement status was determined for those who answered for the first time that they were retired. Approximately $49 \%$ of the workers in our sample retired between 1966 and 1983. In 1983, 1554 workers reported that they were retired, 434 individuals were still working and 127 individuals workers were not able to work. 1582 workers died before 1983 .

Our training indicators are based on a question asked in 1966 about whether the respondent ever received formal training. Using the training history prior to 1966 implies that there is a sufficiently long period between training participation and retirement, reducing the likelihood of reversed causality between training investments and retirement preferences. Later in their careers, workers put more weight on their retirement and it is more likely that they base the decision to train in this phase of their career on the prospects to receive company sponsored retirement benefits. ${ }^{4}$ Therefore, we do not use the information on training participation after 1966. The training information of the 1966 wave is used to construct two dummy variables analogous to Johnson (1996). More specifically, we use the answers to the following questions for the training investments prior to 1966 :

(1) Who was the sponsor of the longest training program taken?

(2) Do you still benefit from this training in your current job?

A first dummy variable serves as an indicator for firmspecific training history and equals 1 if workers had ever received training at a company training school. The second dummy variable is a proxy for general training and equals 1 if workers had ever received other kinds of training such as course work at universities or technical institutes, general training courses (English, Math, Science) etc. However, earlycareer participation in specific training might not be relevant anymore for the current job when workers changed jobs. Therefore, we recode the specific training indicator to 0 for workers who indicate that they not use the training in their current job. Moreover, the firm-specific training indicator is coded 0 if we observe job mobility.

In our analysis, we control for the effects of skills depreciation as proxied by the rate of technological change for the industry in which the worker is employed. This technological change variable is based on the rates of change in industry productivity calculated by Jorgenson et al. (1987) for 35 industry sectors. ${ }^{5}$ Building on Bartel and Sicherman (1983), technological change is measured as the rate of change in productivity that is not accounted for by the growth in the quantity and quality of physical and human capital. In their seminal paper, Bartel and Sicherman (1983) showed that it is relevant to make a distinction between the effects of gradual technological change and technological shocks on retirement. We have replicated their two technological change variables. The first variable measures gradual technological change by taking the mean annual rate of technological change over the 10 -year period before period $t$, which characterizes the longrun differences in technological change between industries. The second variable measures technological shocks by taking the unexpected change in the rate of technological change, which is defined as a $z$-score.

Other control variables are non-white, marital status, years of schooling, health limitations, a dummy variable indicating if employees work in the government sector, retirement preferences, 1-year-lagged self-reported wages (in logs), tenure and age of the workers in 1966, the unemployment rate, and indicators for gradual output change and output shocks. The health variable is a lagged variable constructed from answers to questions on the limitations of health in the working situation. The health variable is coded 1 if someone's health limits their ability to work and coded 0 otherwise. In order to further reduce the effects of potential self-selection into jobs that offer high pension coverage we include a variable measuring retirement preferences which is based on the 1966 question regarding whether respondents would stop or continue working if they got enough money to live comfortably. This variable is coded 1 if workers replied that they will stop working and 0 if they were undecided or answered that they will continue working. We assume that workers who indicated that they will stop working, derive more utility from leisure than workers who indicated that they would continue working.

The unemployment rate and output growth indicators are included to account for business cycle effects. The unemployment rate is measured for the civilian noninstitutional population of 16 years and older and is based on Bureau of Labor Statistics (BLS) Household Annual Averages data. Output growth, like the technological change indicators, is divided into two different variables indicating the gradual change and shock in output growth. Following Bartel and Sicherman (1983), the Jorgenson database is used for our indicators of output growth.

Sample means and SDs of selected variables are given in Table 1. The table shows that $49 \%$ of the workers in our sample retire between 1966 and 1983 and 50\% is subject to a mandatory retirement plan. The mandatory retirement age lies between 52 and 72 years. However, a large majority $(66 \%)$ has a compulsory retirement age of 65 . Approximately $4 \%$ of all the workers have a firm-specific training background that is still relevant for their current job, while 19\% have a general training history. Furthermore, only $3 \%$ of all workers with firm-specific skills continue working in the year after the first time they retired. This percentage is much higher among those with general skills $(20 \%)$. The mean gradual technological change is rather low at $0.6 \%$. The table further shows that $32 \%$ of all workers are non-white and $83 \%$ are married. On average, the workers in our sample have 9 years of education,

\footnotetext{
${ }^{4}$ Montizaan et al. (2010) focused on the impact of the abolishment of generous early retirement systems on training participation and found, consistent with human capital theory, that postponement of retirement due to shocks to pension rights has a positive impact on the training participation of older men.

${ }^{5}$ As technological change variables such as 'research and development intensity' and the 'extent of computer usage' are not available for all industry sectors, we use the indirect measures of Jorgenson et al. (1987).
} 
Table 1. Descriptive statistics

\begin{tabular}{|c|c|c|c|c|c|}
\hline & Min & Max & Mean & SD & $\begin{array}{l}\text { Dummy: } \% \\
\text { Obs. coded } 1\end{array}$ \\
\hline Retirement & 0 & 1 & & & 48.80 \\
\hline Mandatory retirement plan & 0 & 1 & & & 49.57 \\
\hline Mandatory retirement age & 52.00 & 72.00 & 65.90 & 2.54 & \\
\hline Firm-specific training & 0 & 1 & & & 4.05 \\
\hline General training & 0 & 1 & & & 18.79 \\
\hline $\begin{array}{l}\text { Working } 1 \text { year after retirement } \\
\text { (firm-specific training) }\end{array}$ & 0 & 1 & & & 2.80 \\
\hline $\begin{array}{l}\text { Working } 1 \text { year after retirement } \\
\text { (general training) }\end{array}$ & 0 & 1 & & & 20.45 \\
\hline Gradual technological change & -0.15 & 0.03 & 0.01 & 0.01 & \\
\hline Technological shocks & -4.05 & 4.86 & -0.17 & 1.37 & \\
\hline Non-white & 0 & 1 & & & 31.59 \\
\hline Marital status & 0 & 1 & & & 83.84 \\
\hline Years of schooling & 0 & 18.00 & 9.24 & 3.90 & \\
\hline Health limitations & 0 & 1 & & & 35.32 \\
\hline Government employee & 0 & 1 & & & 19.66 \\
\hline Retirement preferences & 0 & 1 & & & 22.11 \\
\hline Wage level & 100.00 & 50000.00 & 6276.18 & 4407.11 & \\
\hline Tenure & 0 & 67.00 & 15.04 & 12.10 & \\
\hline Age in 1966 & 45.00 & 59.00 & 51.50 & 4.27 & \\
\hline Unemployment & 3.50 & 9.60 & 6.57 & 1.84 & \\
\hline Output growth & -0.04 & 0.27 & 0.04 & 0.02 & \\
\hline Output shock & -5.25 & 15.35 & -0.049 & 3.07 & \\
\hline
\end{tabular}

Notes: $N=4549$. In this table, we give the percentage of workers who retired between 1966 and 1983. Observations are censored after the first retirement or until individuals dropped out of the survey. The firm-specific training and general training indicators are based on the question asked in 1966 about whether workers had ever received formal training. Gradual technological change is the mean of yearly rates of change in industrial productivity based on Jorgenson et al. (1987). The variable which measures unexpected technological shocks is defined as a $z$-score. Output growth and output shocks are calculated analogous to our gradual technological change and technological shock indicators. The wage level is converted to constant 1966 dollars.

$35 \%$ experiences health limitations and $20 \%$ are government employees. Workers have an average tenure of 15 years, are 51 years-old in 1966 and 22\% indicate that they will stop working if they get enough money to live comfortably.

We limit our analysis to workers who were not selfemployed. Workers who reported a monthly wage below $\$ 100$ are also excluded from our analysis. This reduces our sample to 4549 respondents. Due to item-nonresponse on the variables of interest, the estimation sample is further reduced to 3624 men.

\section{Empirical Strategy}

In our empirical analysis we examine how the training background of workers affects retirement. To assess this relation, we follow the studies of Coile $(2004 a, b)$, Coile and Levine (2006, 2007) and Coile and Gruber (2007) by estimating the following equation:

$$
\begin{aligned}
\text { Retire }_{i t}= & \beta_{0}+\beta_{1} \text { FStraining }_{i t}+\beta_{2} \text { GEtraining }_{i t} \\
& +\beta_{3} X_{i t}+\gamma_{a}+\gamma_{t}+\varepsilon_{i t}
\end{aligned}
$$

where Retire is a dummy equal to 1 if individual $i$ at age $a$ at time $t$ retires and FStraining is the dummy measuring whether a worker had received firm-specific training and GEtraining is the dummy indicating whether a worker has a general training background. $X$ represents a vector including personal characteristics, sector specific technological change indicators and either the sector-specific unemployment rate or output growth indicators. Finally, $\gamma_{a}$ represents age-fixed effects, $\gamma_{t}$ represents time-fixed effects. The age-fixed effects incorporate the different individual retirement propensities at different ages and essentially converts this model into a discrete proportional hazard model. Following Coile and Levine (2007), we estimate this regression as a pooled linear probability model in which we cluster $\varepsilon$ over individuals. We also used probit and Cox proportional hazard models instead and found that our results are robust to the econometric method used.

\section{Results}

\section{Training and retirement patterns}

We begin our analyses with a simple graph showing the nonparametric hazard function from employment to retirement for the workers with a firm-specific or general training background. The nonparametric estimates of the hazard rate are based on the Kaplan-Meier estimator. Figure 1 shows that the hazard rates for both groups of workers are identical until the age of 63. At the common mandatory retirement age of 65 we observe a clear peak in the hazard function for those with firm-specific skills or general skills. Consistent with the prediction that employers enter into implicit contracts that 


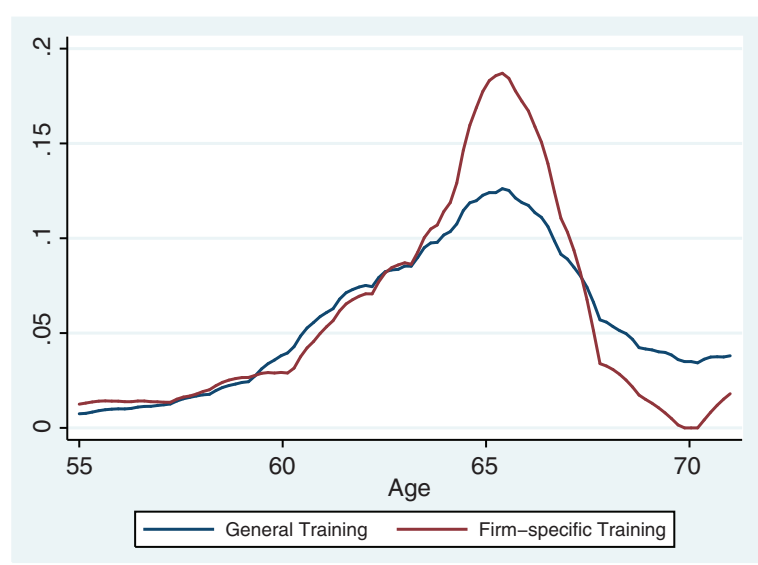

Fig. 1. Hazard rates by training background

Note: This figure shows the nonparametric hazard rates based on the Kaplan-Meier estimator.

consist of upward sloping earning profiles and compulsory retirement after firm-specific training investments, this peak is much higher for the workers with a firm-specific training background. The group of workers with firm-specific skills that retire late (i.e., after the age of 65) is relatively small compared to those with a general training background, implying that the hazard rate of the latter is higher. The figure clearly indicates that the difference in the treatment of workers with firm-specific and general skills have large consequences for retirement patterns and that workers with firm-specific skills have fewer and potentially less favourable options to continue working after the mandatory retirement age of 65 .

Table 2 presents the estimation results of the linear probability models as specified in Equation 1. ${ }^{6}$ The estimation results in Column 1 show that the human-capital variables affect workers' retirement behaviour significantly in the way that we expect. We find that workers with firm-specific training skills have a significantly lower likelihood to retire late (i.e., firm-specific training increases the likelihood of retirement by $2.5 \%$ ), while we do not find any effect of general skills on retirement behaviour.

Considering the results for the other variables, we find that the results for the technological change indicators deviate from the earlier findings of Bartel and Sicherman (1993). We do not find that gradual technological change and technological shocks have a significant effect on the likelihood to retire. The likelihood to retire is lower for non-white workers and workers with more years of schooling. Workers who experience health limitations, government employees and those with strong retirement preferences have a greater likelihood of retiring earlier. ${ }^{7}$

Column 2 of Table 2 presents the same analysis with interaction effects between technological shocks and our training indicators. The interaction effects between technological shocks and the training indicators give an indication of the effects of stochastic changes in the value of marginal product on the labour market position of workers with firm-specific or general training. As the table shows, including these interaction effects does not lead to large deviations from our initial results. The size of the coefficient of the firm-specific training indicator does not change and the coefficient of the interaction effect between firm-specific training and the indicator for technological shocks is not statistically significant. This shows that firms do not dispose of their older workers in periods when an adverse shock in productivity occurs. ${ }^{8}$ The interaction effect for workers with general skills is negative but statistically insignificant.

Subsequently adding controls for business cycle effects (Columns 3 and 4) does not lead to different results from our earlier findings. The firm-specific training background of workers continues to have a significantly negative effect on the likelihood of late retirement, indicating the robustness of our earlier findings. Furthermore, the coefficients of gradual technological change and technological shocks remain insignificantly different from zero.

\section{Mandatory retirement}

The previous results suggest that workers with firm-specific and general skills are treated differently and that the former have less options to continue working after the compulsory retirement age of 65 . Table 3 presents estimates which pursue this issue further by showing correlations between human capital investments, the incidence of mandatory retirement and the mandatory retirement age. Column 1 of Table 3 shows the estimation results of linear probability models on a dummy indicator which equals 1 if workers are subject to a mandatory retirement plan at their present job. The estimation results show that workers with firm-specific skills are significantly more often subject to compulsory retirement. The incidence of compulsory retirement among these workers is approximately $14.3 \%$ higher. Oppositely, the coefficient of general training is not significant. We also have information on the retirement age which is agreed upon in the compulsory retirement plan. To analyse more closely whether the difference in the hazard rates at age 65 between the workers with firm-specific or general skills is correlated to mandatory retirement, we use this information to construct a dummy variable that equals 1 if the compulsory retirement age is 65 and 0 otherwise. Column 2 shows that the incidence of workers with a compulsory retirement plan that forces them to retire at the age of 65

${ }^{6}$ Life-cycle literature predicts that firm-specific training increases tenure so that firms can benefit from the rents resulting from the investment. We analysed whether this assumption holds by estimating the correlation between training and tenure rates with Ordinary Least Squares (OLS) (including various control variables). We found that a worker's firm-specific training background is significantly positively correlated with tenure. Conversely, a general training background is significantly negatively correlated with tenure. These results remain robust when adding occupation fixed effects and when accounting for selectivity.

${ }^{7} \mathrm{We}$ also estimated the model without including retirement preferences as a regressor and find that the coefficients of our training variables are not affected by the inclusion of this variable.

${ }^{8}$ Due to the imperfect measurement of training and the fact that we do not observe productivity at an individual level, we cannot draw direct conclusions from these results. 
Table 2. Retirement, training background and technological change

\begin{tabular}{|c|c|c|c|c|}
\hline $\begin{array}{l}\text { Dependent variable: } \\
\text { retirement }\end{array}$ & (1) & $(2)$ & (3) & (4) \\
\hline Firm-specific training & $\begin{array}{l}0.025^{* *} \\
(0.010)\end{array}$ & $\begin{array}{l}0.027 * * \\
(0.011)\end{array}$ & $\begin{array}{l}0.027^{* *} \\
(0.011)\end{array}$ & $\begin{array}{l}0.028^{* *} \\
(0.011)\end{array}$ \\
\hline General training & $\begin{array}{c}0.007 \\
(0.005)\end{array}$ & $\begin{array}{c}0.007 \\
(0.005)\end{array}$ & $\begin{array}{c}0.007 \\
(0.005)\end{array}$ & $\begin{array}{c}0.007 \\
(0.005)\end{array}$ \\
\hline Gradual technological change (divided by 100 ) & $\begin{array}{c}-0.003 \\
(0.003)\end{array}$ & $\begin{array}{c}-0.003 \\
(0.003)\end{array}$ & $\begin{array}{c}-0.003 \\
(0.003)\end{array}$ & $\begin{array}{c}-0.001 \\
(0.003)\end{array}$ \\
\hline Technological shocks & $\begin{array}{c}0.110 \\
(0.126)\end{array}$ & $\begin{array}{c}0.128 \\
(0.137)\end{array}$ & $\begin{array}{c}0.128 \\
(0.137)\end{array}$ & $\begin{array}{c}0.038 \\
(0.161)\end{array}$ \\
\hline Int. technological shocks and firm-specific training & & $\begin{array}{c}0.841 \\
(0.847)\end{array}$ & $\begin{array}{l}0.841 \\
(0.847)\end{array}$ & $\begin{array}{l}0.807 \\
(0.849)\end{array}$ \\
\hline Int. technological shocks and general training & & $\begin{array}{c}-0.186 \\
(0.258)\end{array}$ & $\begin{array}{c}-0.186 \\
(0.258)\end{array}$ & $\begin{array}{c}-0.175 \\
(0.258)\end{array}$ \\
\hline Non-white & $\begin{array}{l}-0.013 * * * \\
(0.005)\end{array}$ & $\begin{array}{l}-0.013^{* * *} \\
(0.005)\end{array}$ & $\begin{array}{l}-0.013 * * * \\
(0.005)\end{array}$ & $\begin{array}{l}-0.013^{* * * *} \\
(0.005)\end{array}$ \\
\hline Marital status & $\begin{array}{c}-0.004 \\
(0.007)\end{array}$ & $\begin{array}{c}-0.004 \\
(0.007)\end{array}$ & $\begin{array}{c}-0.004 \\
(0.007)\end{array}$ & $\begin{array}{c}-0.004 \\
(0.007)\end{array}$ \\
\hline Years of schooling & $\begin{array}{r}-0.114^{*} \\
(0.063)\end{array}$ & $\begin{array}{c}-0.114^{*} \\
(0.063)\end{array}$ & $\begin{array}{c}-0.114 * \\
(0.063)\end{array}$ & $\begin{array}{c}-0.115^{*} \\
(0.063)\end{array}$ \\
\hline Health limitations & $\begin{array}{l}0.072 * * * \\
(0.005)\end{array}$ & $\begin{array}{l}0.072 * * * \\
(0.005)\end{array}$ & $\begin{array}{l}0.072 * * * \\
(0.005)\end{array}$ & $\begin{array}{l}0.073 * * * \\
(0.005)\end{array}$ \\
\hline Government employee & $\begin{array}{l}0.037 * * * \\
(0.007)\end{array}$ & $\begin{array}{l}0.037 * * * \\
(0.007)\end{array}$ & $\begin{array}{l}0.037 * * * \\
(0.007)\end{array}$ & $\begin{array}{l}0.037 * * * \\
(0.007)\end{array}$ \\
\hline Commitment to work & $\begin{array}{l}-0.023 * * * \\
(0.004)\end{array}$ & $\begin{array}{l}-0.023 * * * \\
(0.004)\end{array}$ & $\begin{array}{l}-0.023^{* * * *} \\
(0.004)\end{array}$ & $\begin{array}{l}-0.023 * * * \\
(0.004)\end{array}$ \\
\hline Log wage & $\begin{array}{c}0.073 \\
(0.403)\end{array}$ & $\begin{array}{c}0.071 \\
(0.403)\end{array}$ & $\begin{array}{l}0.071 \\
(0.403)\end{array}$ & $\begin{array}{c}0.077 \\
(0.403)\end{array}$ \\
\hline Unemployment & & & $\begin{array}{l}0.032^{* * *} \\
(0.004)\end{array}$ & \\
\hline Gradual output change & & & & $\begin{array}{l}-0.823^{* * * *} \\
(0.203)\end{array}$ \\
\hline Output shocks & & & & $\begin{array}{c}-0.001^{*} \\
(0.000)\end{array}$ \\
\hline Constant & $\begin{array}{l}-0.036 \\
(0.032)\end{array}$ & $\begin{array}{r}-0.036 \\
(0.032)\end{array}$ & $\begin{array}{l}-0.160 * * * \\
(0.036)\end{array}$ & $\begin{array}{c}-0.025 \\
(0.032)\end{array}$ \\
\hline Observations & 17869 & 17869 & 17869 & 17869 \\
\hline$R$-squared & 0.249 & 0.249 & 0.249 & 0.249 \\
\hline
\end{tabular}

Notes: Clustered SEs are in parentheses.

$* * *<0.01, * *<0.05, *<0.10$.

is $12.6 \%$ higher among those who have acquired firm-specific skills. As a robustness analysis, we also estimated a multinomial logistic regression on a variable measuring whether the compulsory retirement age was below 65 , at the age of 65 or after the age of 65 (regression results available upon request). The reference category included all workers who did not have a compulsory retirement plan. The results of this analysis showed that firm-specific skills are only significantly positively correlated to retirement at the age of 65 while no significant correlation is found between general skills and retirement behaviour.

\section{Alternative training indicator}

Table 4 presents the results of analyses with an alternative training indicator. This training indicator contains information on workers' pre-1966 training participation as well as their training participation after 1966. As the likelihood of causality problems (between training investments and retirement) rises with the use of training data after 1966, we only include the training incidence of workers who participated in company sponsored training when they were aged 50 or younger. The newly constructed training indicators are based on the available data in 1966, 1967, 1969, 1971, 1976 and 1981. The firm-specific training indicator now equals 1 if workers participated in company-sponsored training before the age of 51 and still benefit from this training in their present work. Again, training participation is coded 0 for workers who changed jobs after they participated in the training course. The general training variable equals 1 if workers younger than 51 years responded that they participated in other forms of training and zero otherwise.

Using this alternative training indicator, we again find that workers who participated in firm-specific training have a significant higher probability to retire earlier (Column 1). Columns 2 and 3 further indicate that mandatory retirement at the age of 65 for those with firm-specific skills is responsible for this specific retirement pattern. Hence, we can conclude that our results are robust to the inclusion of information on training information after 1966. 
Table 3. Compulsory retirement and training background

\begin{tabular}{|c|c|c|}
\hline Dependent variable & $\begin{array}{l}\text { (1) } \\
\text { Mandatory } \\
\text { retirement }\end{array}$ & $\begin{array}{l}(2) \\
\text { Mandatory } \\
\text { retirement } \\
\text { at age } 65\end{array}$ \\
\hline Firm-specific training & $\begin{array}{l}0.143^{* * *} \\
(0.031)\end{array}$ & $\begin{array}{l}0.126^{* * * *} \\
(0.038)\end{array}$ \\
\hline General training & $\begin{array}{c}0.021 \\
(0.016)\end{array}$ & $\begin{array}{l}0.028^{*} \\
(0.016)\end{array}$ \\
\hline $\begin{array}{l}\text { Gradual technological } \\
\text { change (divided by } 100 \text { ) }\end{array}$ & $\begin{array}{c}-0.001 \\
(0.004)\end{array}$ & $\begin{array}{c}-0.006 \\
(0.006)\end{array}$ \\
\hline Technological shocks & $\begin{array}{l}0.587 * * \\
(0.263)\end{array}$ & $\begin{array}{l}0.818 * * * \\
(0.254)\end{array}$ \\
\hline $\begin{array}{l}\text { Int. technological shocks } \\
\text { and firm-specific } \\
\text { training }\end{array}$ & $\begin{array}{c}-0.346 \\
(1.249)\end{array}$ & $\begin{array}{c}-0.061 \\
(1.435)\end{array}$ \\
\hline $\begin{array}{l}\text { Int. technological shocks } \\
\text { and general training }\end{array}$ & $\begin{array}{c}0.839 * \\
(0.495)\end{array}$ & $\begin{array}{c}0.447 \\
(0.503)\end{array}$ \\
\hline Non-white & $\begin{array}{l}0.047^{* * * *} \\
(0.014)\end{array}$ & $\begin{array}{c}0.008 \\
(0.014)\end{array}$ \\
\hline Marital status & $\begin{array}{c}0.022 \\
(0.018)\end{array}$ & $\begin{array}{l}0.031^{*} \\
(0.016)\end{array}$ \\
\hline Years of schooling & $\begin{array}{l}0.702 * * * \\
(0.197)\end{array}$ & $\begin{array}{c}0.075 \\
(0.184)\end{array}$ \\
\hline Health limitations & $\begin{array}{c}0.002 \\
(0.011)\end{array}$ & $\begin{array}{r}-0.009 \\
(0.010)\end{array}$ \\
\hline Government employee & $\begin{array}{l}0.404^{* * *} \\
(0.021)\end{array}$ & $\begin{array}{l}0.149^{* * * *} \\
(0.022)\end{array}$ \\
\hline Commitment to work & $\begin{array}{l}-0.045^{* * *} \\
(0.015)\end{array}$ & $\begin{array}{l}-0.033 * * \\
(0.015)\end{array}$ \\
\hline Log wage & $\begin{array}{l}7.941 * * * \\
(0.841)\end{array}$ & $\begin{array}{l}4.227 * * * \\
(0.733)\end{array}$ \\
\hline Gradual output change & $\begin{array}{l}0.845^{* *} \\
(0.368)\end{array}$ & $\begin{array}{l}0.779 * * \\
(0.369)\end{array}$ \\
\hline Output shocks & $\begin{array}{c}-0.001 * \\
(0.001)\end{array}$ & $\begin{array}{c}-0.001 \\
(0.001)\end{array}$ \\
\hline Constant & $\begin{array}{l}-0.532 * * * \\
(0.070)\end{array}$ & $\begin{array}{l}-0.228^{* * * *} \\
(0.063)\end{array}$ \\
\hline Observations & 15302 & 15304 \\
\hline$R$-squared & 0.288 & 0.187 \\
\hline
\end{tabular}

Notes: Clustered SEs are in parentheses. The specifications in this table includes all control variables as specified in Column 4 of Table 2.

$* * *<0.01, * *<0.05, *<0.10$.
Table 4. Retirement, training background (including training incidence after 1966)

\begin{tabular}{|c|c|c|c|}
\hline Dependent variable & $\begin{array}{l}\text { (1) } \\
\text { Retirement }\end{array}$ & $\begin{array}{l}(2) \\
\text { Mandatory } \\
\text { retirement }\end{array}$ & $\begin{array}{l}\text { (3) } \\
\text { Mandatory } \\
\text { retirement } \\
\text { at age } 65\end{array}$ \\
\hline Firm-specific training & $\begin{array}{l}0.022 * * * \\
(0.008)\end{array}$ & $\begin{array}{l}0.149 * * * \\
(0.027)\end{array}$ & $\begin{array}{l}0.127 * * * \\
(0.032)\end{array}$ \\
\hline General training & $\begin{array}{c}0.004 \\
(0.005)\end{array}$ & $\begin{array}{c}0.002 \\
(0.019)\end{array}$ & $\begin{array}{c}0.006 \\
(0.019)\end{array}$ \\
\hline $\begin{array}{l}\text { Gradual technological } \\
\text { change (divided by 100) }\end{array}$ & $\begin{array}{c}-0.001 \\
(0.003)\end{array}$ & $\begin{array}{c}-0.001 \\
(0.004)\end{array}$ & $\begin{array}{c}-0.006 \\
(0.006)\end{array}$ \\
\hline Technological shocks & $\begin{array}{l}0.101 \\
(0.160)\end{array}$ & $\begin{array}{l}0.682 * * * \\
(0.257)\end{array}$ & $\begin{array}{l}0.793 * * * \\
(0.248)\end{array}$ \\
\hline $\begin{array}{l}\text { Int. technological shocks } \\
\text { and firm-specific } \\
\text { training }\end{array}$ & $\begin{array}{c}-0.194 \\
(0.700)\end{array}$ & $\begin{array}{l}-0.800 \\
(1.127)\end{array}$ & $\begin{array}{c}0.415 \\
(1.257)\end{array}$ \\
\hline $\begin{array}{l}\text { Int. technological shocks } \\
\text { and general training }\end{array}$ & $\begin{array}{l}-0.408 \\
(0.279)\end{array}$ & $\begin{array}{c}0.708 \\
(0.550)\end{array}$ & $\begin{array}{l}0.756 \\
(0.559)\end{array}$ \\
\hline Non-white & $\begin{array}{l}-0.014 * * * \\
(0.005)\end{array}$ & $\begin{array}{l}0.046^{* * *} \\
(0.014)\end{array}$ & $\begin{array}{c}0.006 \\
(0.014)\end{array}$ \\
\hline Marital status & $\begin{array}{c}-0.004 \\
(0.007)\end{array}$ & $\begin{array}{c}0.021 \\
(0.018)\end{array}$ & $\begin{array}{l}0.030^{*} \\
(0.016)\end{array}$ \\
\hline Years of schooling & $\begin{aligned}-0.111 * \\
(0.064)\end{aligned}$ & $\begin{array}{l}0.714^{* * * *} \\
(0.196)\end{array}$ & $\begin{array}{c}0.097 \\
(0.183)\end{array}$ \\
\hline Health limitations & $\begin{array}{l}0.072 * * * \\
(0.005)\end{array}$ & $\begin{array}{c}0.002 \\
(0.011)\end{array}$ & $\begin{array}{r}-0.010 \\
(0.010)\end{array}$ \\
\hline Government employee & $\begin{array}{l}0.037 * * * \\
(0.007)\end{array}$ & $\begin{array}{l}0.400^{* * *} \\
(0.021)\end{array}$ & $\begin{array}{l}0.146^{* * *} \\
(0.022)\end{array}$ \\
\hline Commitment to work & $\begin{array}{l}-0.023 * * * \\
(0.004)\end{array}$ & $\begin{array}{l}-0.045^{* * *} \\
(0.015)\end{array}$ & $\begin{array}{l}-0.032 * * \\
(0.015)\end{array}$ \\
\hline Log wage & $\begin{array}{c}0.084 \\
(0.402)\end{array}$ & $\begin{array}{l}7.867 * * * \\
(0.836)\end{array}$ & $\begin{array}{l}4.215^{* * *} \\
(0.729)\end{array}$ \\
\hline Gradual output change & $\begin{array}{l}-0.808 * * * \\
(0.203)\end{array}$ & $\begin{array}{l}0.911^{* *} \\
(0.370)\end{array}$ & $\begin{array}{l}0.838^{* *} \\
(0.370)\end{array}$ \\
\hline Output shocks & $\begin{array}{r}-0.001^{*} \\
(0.000)\end{array}$ & $\begin{array}{c}-0.001 \\
(0.001)\end{array}$ & $\begin{array}{c}-0.001 \\
(0.001)\end{array}$ \\
\hline Constant & $\begin{array}{c}-0.028 \\
(0.032)\end{array}$ & $\begin{array}{c}-0.533^{* * *} \\
(0.069)\end{array}$ & $\begin{array}{c}-0.233^{* * *} \\
(0.063)\end{array}$ \\
\hline Observations & 17872 & 15304 & 15306 \\
\hline$R$-squared & 0.250 & 0.289 & 0.188 \\
\hline \multicolumn{4}{|c|}{$\begin{array}{l}\text { Notes: Clustered SEs are in parentheses. The constructed training } \\
\text { indicators are based on data from 1966, 1967, 1969, 1971, } 1976 \\
\text { and } 1981 \text { and equal to } 1 \text { if workers younger than } 51 \text { years, } \\
\text { indicating that they had received company sponsored training and } \\
\text { still benefit from this training in their present work (corrected for } \\
\text { job mobility) or received general training. The specifications } \\
\text { includes all control variables as specified in Column } 4 \text { of Table } 2 . \\
* * *<0.01, * *<0.05, *<0.10 \text {. }\end{array}$} \\
\hline
\end{tabular}

Notes: Clustered SEs are in parentheses. The constructed training indicators are based on data from 1966, 1967, 1969, 1971, 1976 and 1981 and equal to 1 if workers younger than 51 years, indicating that they had received company sponsored training and still benefit from this training in their present work (corrected for job mobility) or received general training. The specifications includes all control variables as specified in Column 4 of Table 2. $* * *<0.01, * *<0.05, *<0.10$

(over time) of all time-varying regressors in our model. The benefit of the inclusion of the Mundlak terms is that the correlation between the unobservables and the observables acts only through the time averages of the observable variables, while the remaining part of the unobserved effect is independent of the observables (Mundlak, 1978). Table 5 shows the results of the random effect model including the Mundlak terms. It becomes clear from the table that our results are not affected by the correction for unobserved heterogeneity. The coefficients of the training indicators, as well as those of the control variables, do not significantly differ

from those in our previous estimations. A Wald-test reveals additional Mundlak terms which are the mean values that the error terms are random and not correlated with the
observable variables. We relax this assumption by including

\section{Accounting for the influence of unobserved characteristics} training taken long before the retirement date and by correcting for the commitment to work which can be seen as for retirement preferences, we cannot entirely rule characteristics. Ideally, we would like to have included fixe effects into our model. However, given the fact that there is not much variation over time in our training variables, we estimate a random effects model. This model is built on the assumption that the error terms are random and not correlated with the
observable variables. We relax this assumption by including 
Table 5. Robustness analyses: accounting for unobserved heterogeneity

\begin{tabular}{|c|c|c|c|}
\hline Dependent variable & $\begin{array}{l}\text { (1) } \\
\text { Retirement }\end{array}$ & $\begin{array}{l}\text { (2) } \\
\text { Mandatory } \\
\text { retirement }\end{array}$ & $\begin{array}{l}\text { (3) } \\
\text { Mandatory } \\
\text { retirement } \\
\text { at age } 65\end{array}$ \\
\hline Firm-specific training & $\begin{array}{l}0.026 * * \\
(0.011)\end{array}$ & $\begin{array}{l}0.099 * * * \\
(0.028)\end{array}$ & $\begin{array}{l}0.106^{* * * *} \\
(0.028)\end{array}$ \\
\hline General training & $\begin{array}{c}0.007 \\
(0.005)\end{array}$ & $\begin{array}{c}0.010 \\
(0.015)\end{array}$ & $\begin{array}{c}0.017 \\
(0.015)\end{array}$ \\
\hline $\begin{array}{l}\text { Gradual technological } \\
\text { change (divided } \\
\text { by } 100 \text { ) }\end{array}$ & $\begin{array}{c}-0.001 \\
(0.003)\end{array}$ & $\begin{array}{c}-0.001 \\
(0.004)\end{array}$ & $\begin{array}{c}-0.004 \\
(0.004)\end{array}$ \\
\hline Technological shocks & $\begin{array}{c}0.037 \\
(0.182)\end{array}$ & $\begin{array}{c}0.320 \\
(0.242)\end{array}$ & $\begin{array}{l}0.575^{* *} \\
(0.240)\end{array}$ \\
\hline $\begin{array}{l}\text { Int. technological } \\
\text { shocks and firm- } \\
\text { specific training }\end{array}$ & $\begin{array}{c}0.766 \\
(0.843)\end{array}$ & $\begin{array}{c}-0.623 \\
(1.153)\end{array}$ & $\begin{array}{c}-0.030 \\
(1.144)\end{array}$ \\
\hline $\begin{array}{l}\text { Int. technological } \\
\text { shocks and general } \\
\text { training }\end{array}$ & $\begin{array}{c}-0.182 \\
(0.319)\end{array}$ & $\begin{array}{c}0.388 \\
(0.436)\end{array}$ & $\begin{array}{c}0.333 \\
(0.433)\end{array}$ \\
\hline Non-white & $\begin{array}{c}-0.014 * * * \\
(0.005)\end{array}$ & $\begin{array}{l}0.049 * * * \\
(0.014)\end{array}$ & $\begin{array}{c}0.009 \\
(0.014)\end{array}$ \\
\hline Marital status & $\begin{array}{c}0.011 \\
(0.012)\end{array}$ & $\begin{array}{c}0.007 \\
(0.017)\end{array}$ & $\begin{array}{c}0.020 \\
(0.017)\end{array}$ \\
\hline Years of schooling & $\begin{array}{c}-0.137 * * \\
(0.063)\end{array}$ & $\begin{array}{l}0.449 * * \\
(0.192)\end{array}$ & $\begin{array}{c}0.000 \\
(0.191)\end{array}$ \\
\hline Health limitations & $\begin{array}{l}0.069^{* * * *} \\
(0.006)\end{array}$ & $\begin{array}{c}0.005 \\
(0.008)\end{array}$ & $\begin{array}{c}0.005 \\
(0.008)\end{array}$ \\
\hline Government employee & $\begin{array}{l}0.029^{* *} \\
(0.014)\end{array}$ & $\begin{array}{l}0.258^{* * * *} \\
(0.019)\end{array}$ & $\begin{array}{l}0.077 * * * \\
(0.019)\end{array}$ \\
\hline Commitment to work & $\begin{array}{c}-0.023^{* * * *} \\
(0.005)\end{array}$ & $\begin{array}{c}-0.056^{* * *} \\
(0.014)\end{array}$ & $\begin{array}{c}-0.042 * * * \\
(0.014)\end{array}$ \\
\hline Log wage & $\begin{array}{c}-0.128 \\
(0.483)\end{array}$ & $\begin{array}{l}3.455^{* * * *} \\
(0.706)\end{array}$ & $\begin{array}{l}2.378 * * * \\
(0.701)\end{array}$ \\
\hline $\begin{array}{l}\text { Gradual output } \\
\text { change }\end{array}$ & $\begin{array}{l}-0.822 * * * \\
(0.208)\end{array}$ & $\begin{array}{l}0.704^{* *} \\
(0.288)\end{array}$ & $\begin{array}{l}0.811^{* * *} \\
(0.286)\end{array}$ \\
\hline Output shocks & $\begin{array}{c}-0.001 \\
(0.001)\end{array}$ & $\begin{array}{c}-0.000 \\
(0.001)\end{array}$ & $\begin{array}{c}0.000 \\
(0.001)\end{array}$ \\
\hline Constant & $\begin{array}{c}0.002 \\
(0.041)\end{array}$ & $\begin{array}{c}-0.683 * * * \\
(0.102)\end{array}$ & $\begin{array}{c}-0.289 * * * \\
(0.102)\end{array}$ \\
\hline Observations & 17869 & 15302 & 15304 \\
\hline Number of individuals & 3624 & 3517 & 3517 \\
\hline
\end{tabular}

Notes: SEs are in parentheses. The random effects estimations shown in this table include all control variables as specified in Column 4 of Table 2 and Mundlak terms for all time varying independent variables.

$* * *<0.01, * *<0.05$.

further that the Mundlak terms are not jointly significant $\left(\chi^{2}\right.$ of 41.00 with a $p$-value of 0.47$).^{9}$

\section{Conclusion}

In this article, we analyse the relation between workers' training backgrounds and retirement patterns. The main finding is that workers with a firm-specific training background more often retire on a high age than workers with a general training background. This suggests that shared investments in firm-specific training are embedded in implicit contracts that aim to decrease turnover, but simultaneously restrict the retirement age. Conversely, firms are less likely to enter into implicit contracts with workers who invest in general skills in their early careers. Additional regressions show that workers with firm-specific skills have indeed more often a compulsory mandatory plan which refrains them from working after the age of 65 . The results are robust to the use of alternative training indicators and correcting for unobserved heterogeneity.

Our estimation results are highly relevant for European and other industrialized countries that are developing public policies that aim to increase labour force participation of older workers in order to face the problems associated with an ageing population. Most European countries have only recently started changing their mandatory retirement laws and still have extensive defined benefit pension plans, which implies that the present legal environment in these countries is comparable with the situation in the US before 1986. As our study demonstrates, the effectiveness of new institutional arrangements to postpone retirement and to establish more flexible retirement will also depend on firms' training policies and the type of skills that workers acquired in the past.

\section{Acknowledgements}

We are indebted to Lex Borghans, Didier Fouarge, Daniel Hamermesh, Ben Kriechel, Pierre Mohnen, Gerhard Pfann, Jan Van Ours and Maarten Vendrik for their valuable comments. We thank Ann Bartel, Nachum Sicherman and Dale Jorgenson for providing us with the industry measures of productivity growth.

\section{References}

Bartel, A. P. and Sicherman, N. (1993) Technological change and retirement decisions of older workers, Journal of Labor Economics, 11, 162-83.

Blinder, A. S. (1982) Private pensions and public pensions: theory and fact, NBER Working Paper No. 902

Coile, C. (2004a) Health shocks and couples labor supply decisions, NBER Working Paper No. 10810

Coile, C. (2004b) Retirement incentives and couples' retirement decisions, Topics in Economic Analysis and Policy, 4, Article 17.

Coile, C. and Gruber, J. (2007) Future social security entitlements and the retirement decision, Review of Economics and Statistics, 89, 234-46.

Coile, C. and Levine, P. (2006) Bulls, bears and retirement behavior, Industrial and Labor Relations Review, 59, 408-29.

Coile, C. and Levine, P. (2007) Labor market shocks and retirement: do government programms matter? Journal of Public Economics, 91, 1901-19.

Dorsey, S. and Macpherson, D. A. (1997) Pensions and training, Industrial Relations, 36, 81-96. ${ }^{9}$ In order to deal with potential self selection of workers into sectors that are more likely to provide mandatory retirement plans,
we also performed regression analyses in which we added the average percentage of workers with a mandatory retirement plan by
sector as a regressor (results available upon requests). The inclusion of this variable does not lead to different coefficients of our training variables. 
Dostie, B. (2011) Wages, productivity and aging, De Economist, 159, 139-58.

Fella, G. (2005) Termination restrictions and investment in general training, European Economic Review, 49, 1480-99.

Johnson, R. W. (1996) The impact of human capital investments on pension benefits, Journal of Labor Economics, 14, 520-54.

Jorgenson, D. W., Gollop, F. M. and Fraumeni, B. (1987) Productivity and US Economic Growth, Harvard University Press, Cambridge.

Kennan, J. (1979) Bonding and the enforcement of labour contracts, Economic Letters, 3, 61-6.

Kotlikoff, L. J. and Gokhale, J. (1992) Estimating a firm's age-productivity profile using the present value of workers' earnings, Quarterly Journal of Economics, 107, 1215-42.
Lazear, E. P. (1979) Why is there mandatory retirement?, Journal of Political Economy, 87, 1261-84.

Lazear, E. P. and Moore, R. L. (1984) Incentives, productivity and labour contracts, Quantitative, Journal of Economics, 99, 275-95.

Medoff, J. L. and Abraham, K. (1981) Are those paid more really more productive? The case of experience, Journal of Human Resources, 16, 186-216.

Montizaan, R., de Grip, A. and Cörvers, F. (2010) Training background and early retirement, Labour Economics, 17, 240-7.

Mundlak, Y. (1978) On the pooling of time series and crosssection data, Econometrica, 46, 69-85.

Wachter, T. V. (2002) The end of mandatory retirement in the US: effects on retirement and implicit contracts, Center for Labor Economics Working Paper No. 49. 